\title{
Role of Elastography in Early Detection of Liver Cirrhosis
}

\author{
David Susanto*, Visakha R. Irawan** \\ * Dr. Sayidiman Regional General Hospital \\ Jl. Pahlawan No. 2, Kabupaten Magetan, Provinsi Jawa Timur, Indonesia \\ ** Adhyaksa General Hospital \\ Jl. Hankam Raya No. 60, Jakarta Timur, Daerah Khusus Ibukota Jakarta, Indonesia \\ Email:visakha.revana@ymail.com
}

\begin{abstract}
Liver cirrhosis is a condition in which the liver slowly deteriorates and is unable to function usually due to chronic, or long lasting, injury. Fibrotic tissue replaces healthy liver tissue and partially blocks the flow of blood through the liver. Fibrosis increases liver stiffness. Liver palpation on the early physical examination has been used to assess liver stiffness. Though, palpation has some limitations, such as highly subjective, very operator dependent, and sometimes even impossible to perform. At present, liver biopsy remains the current gold standard for assessing liver fibrosis, even though the diagnostic accuracy is limited by the specimen size, invasive procedure, and long duration for getting the result. Elastography is an alternative method to liver biopsy in patients with chronic liver disease.
\end{abstract}

Keywords: chronic liver disease, elastography, liver cirrhosis 


\title{
Peranan Elastografi dalam Deteksi Dini Sirosis Hati
}

\author{
David Susanto*, Visakha R. Irawan** \\ * Rumah Sakit Umum Daerah dr. Sayidiman \\ Jl. Pahlawan No. 2, Kabupaten Magetan, Provinsi Jawa Timur, Indonesia \\ ** Rumah Sakit Umum Adhyaksa \\ Jl. Hankam Raya No. 60, Jakarta Timur, Daerah Khusus Ibukota Jakarta, Indonesia \\ Email: visakha.revana@ymail.com
}

\begin{abstract}
Abstrak
Sirosis hati adalah keadaan di mana fungsi hati perlahan-lahan memburuk dan hati tidak dapat melakukan fungsinya secara normal, akibat penyakit hati kronik, ataupun kerusakan hati yang bersifat terus-menerus. Jaringan fibrosis menggantikan jaringan parenkim yang sehat dan mengakibatkan hambatan partial pada aliran darah yang melalui hati. Fibrosis meningkatkan terjadinya pengerasan hati. Palpasi hati pada pemeriksaan fisik biasanya digunakan sebagai pemeriksaan awal pada kasus pengerasan hati. Palpasi memiliki banyak keterbatasan, seperti bersifat subjektif, bergantung dari keterampilan klinis operator, dan terkadang sulit untuk dilakukan. Saat ini, biopsi hati masih merupakan baku emas untuk pemeriksaan fibrosis hati. Namun biopsi hati memiliki keterbatasan, seperti ukuran bahan pemeriksaan yang terbatas, prosedur yang invasif, dan waktu lama yang dibutuhkan untuk mendapatkan hasil pemeriksaan. Elastografi adalah metode alternatif dari biopsi hati pada pasien dengan penyakit hati kronik.
\end{abstract}

Kata kunci: elastografi, penyakit hati kronik, sirosis hati 


\section{Pendahuluan}

Hepatitis merupakan peradangan yang terjadi pada hati, yang dapat disebabkan oleh suatu proses infeksi, seperti virus, bakteri, jamur, dan parasit, atau bukan infeksi, seperti alkohol, obat, autoimun, dan metabolik. Proses peradangan yang terjadi pada hati dapat bersifat akut maupun kronik. Pada keadaan kronik, terjadi peradangan dalam kurun waktu minimal enam bulan dengan tingkat kerusakan yang bervariasi. ${ }^{1}$

Sirosis hati merupakan stadium akhir dari penyakit hati kronik. Pada stadium awal, pasien penyakit sirosis tidak merasakan adanya gejala, sehingga tidak menyadari menderita sirosis dan tidak berobat. Seiring progresivitas penyakit tersebut, sirosis hati akan mencapai tahap yang tidak dapat dikompensasi, sehingga timbul berbagai gejala. Pada tahap ini, telah terbentuk jaringan fibrosis pada jaringan parenkim hati, terjadi penurunan fungsi hati, dan muncul berbagai komplikasi. Berdasarkan laporan World Health Organization (WHO) tahun 2008, angka kematian akibat sirosis hati di Eropa mencapai 1,8\%, yaitu sekitar 170.000 jiwa per tahunnya. ${ }^{1}$ Di Amerika Serikat, hepatitis virus dan hepatitis akibat alkohol menjadi penyebab utama sirosis hati. ${ }^{2}$ Laporan WHO tahun 2014 menyatakan bahwa penyakit hati menduduki peringkat ke delapan penyebab kematian terbanyak di Indonesia dengan angka kematian 3,49\%, yaitu sekitar 48.858 jiwa. $^{3}$

Karena jarangnya ditemukan gejala pada pasien hepatitis kronik, maka diperlukan pemeriksaan penunjang yang dapat digunakan untuk memantau progresivitas dari perjalanan penyakit tersebut. Hingga kini, biopsi hati masih merupakan pemeriksaan baku emas untuk penilaian derajat fibrosis hati, namun pemeriksaan biopsi memiliki beberapa kekurangan, seperti ukuran bahan pemeriksaan yang diambil terbatas sehingga kurang representatif, prosedur yang cenderung invasif, dan membutuhkan waktu yang lama. Dalam beberapa tahun terakhir, telah dikembangkan pemeriksaan penunjang baru, yaitu elastografi. Prosedur pemeriksaan yang relatif cepat dan tidak invasif, serta penerimaaan yang baik oleh pasien, menyebabkan elastografi mulai banyak digunakan sebagai alternatif dari biopsi hati dan rutin dilakukan pada pasien penyakit hati kronik. ${ }^{4}$

\section{Sirosis Hati}

Pada stadium awal sirosis, hati masih berfungsi secara normal, namun dengan berlanjutnya proses kerusakan parenkim yang berkepanjangan, terjadilah fase dekompensasi, di mana didapatkan penurunan fungsi hati. ${ }^{5}$ Keadaan ini juga disertai berbagai komplikasi yang disebabkan gangguan aliran darah yang melalui hati akibat terbentuknya jaringan fibrosis. ${ }^{6}$ Penyakit hepatitis virus dan hepatitis akibat alkohol merupakan penyebab tersering terjadinya 


\section{Review Article}

sirosis hati, sementara itu angka kejadian nonalcoholic fatty liver disease (NAFLD) semakin meningkat seiring dengan bertambahnya angka obesitas. ${ }^{2}$

Penyebab dari sirosis hati adalah hepatitis virus C, penyakit hati akibat alkohol, NAFLD, nonalcoholic steatohepatitis (NASH), hepatitis virus B kronik, hemokromatosis, penyakit Wilson, hepatitis akibat obat, hepatitis akibat bahan kimia, hepatitis akibat infeksi parasit, gagal jantung kronik, serta infeksi virus lainnya, seperti hepatitis virus D dan hepatitis virus E. Hepatitis virus $\mathrm{C}$ disebabkan infeksi virus hepatitis $\mathrm{C}$ yang mengakibatkan peradangan, pembengkakan, dan kerusakan hati yang bersifat kronik. ${ }^{7,8}$ Virus ini dapat ditularkan melalui kontak seksual dengan seseorang yang terinfeksi, kontak darah dari pasien yang terinfeksi, seperti transfusi darah dan penggunaan jarum suntik, serta penularan melalui jalan lahir dari ibu yang terinfeksi kepada bayinya. Penyakit hepatitis virus $\mathrm{C}$ dapat diobati untuk mencegah terjadinya kerusakan hati yang berkepanjangan, namun pasien biasanya baru menyadari terinfeksi setelah memasuki keadaan sirosis. ${ }^{6}$

Penyakit hati akibat alkohol, sebagai penyebab terbanyak kedua, diderita oleh pasien yang mengkonsumsi alkohol dalam jumlah banyak dan waktu yang lama. Sebuah penelitian menyatakan bahwa mengkonsumsi alkohol kurang dari tiga gelas pada wanita dan kurang dari empat gelas pada pria, tidak menyebabkan gangguan hati. ${ }^{6}$

NAFLD adalah penyakit hati yang disebabkan penumpukan lemak dalam hati, bukan akibat alkohol. NASH adalah keadaan di mana terjadi penumpukan lemak disertai reaksi inflamasi dan kerusakan sel hati. Keadaan inflamasi dan kerusakan sel tersebut akan menyebabkan terbentuknya jaringan fibrosis, yang dapat berkembang menjadi sirosis. Penumpukan lemak dalam hati dapat disebabkan berat badan yang berlebihan, diabetes mellitus, hiperlipidemia, dan sindrom metabolik. ${ }^{6}$

Hepatitis virus B kronik, merupakan penyakit infeksi yang disebabkan oleh virus hepatitis B. Infeksi ini menyebabkan terjadinya reaksi inflamasi dan kerusakan yang kronik pada sel hati. Penularan dari virus hepatitis B terjadi melalui kontak darah dan hubungan seksual. ${ }^{6}$

Fibrosis hati disebabkan karena ketidakseimbangan antara sintesis dan degradasi matriks ekstraselular. Ketika terjadi suatu inflamasi, baik yang berasal dari infeksi virus, alkohol, serta perlemakan hati, maka terjadi pelepasan sitokin - sitokin yang membantu teraktivasinya sel stellata. Sel ini akan bertransisi menjadi myofibroblast yang membentuk jaringan kolagen pada hati dan menghambat degradasi dari matriks ekstraseluler. Apabila reaksi inflamasi terjadi terus-menerus pada hati, maka akan terbentuk akumulasi kolagen pada sel hati dan terjadi sirosis hati. ${ }^{7}$ 
Pada fase terkompensasi, pasien sirosis hati sering tidak merasakan adanya gejala sehingga tidak dilakukan pemeriksaan pada pasien tersebut. Pada tahap yang lebih lanjut, hati sudah tidak dapat mengompensasi kerusakan sel, sehingga mulai timbul gejala dan komplikasi. Gejala subjektif yang dapat dirasakan pasien adalah cepat lelah, kehilangan nafsu makan, penurunan berat badan yang signifikan, mual, perut kembung, edema pada anggota gerak, spider angioma pada kulit, serta ikterus pada sklera dan kulit. ${ }^{6,8}$

Salah satu komplikasi dari sirosis hati adalah hipertensi portal. Keadaan ini terjadi akibat sumbatan pada aliran darah darah pada sinusoid dalam hati karena terdesak oleh jaringan fibrosis, sehingga menyebabkan peningkatan tekanan vena porta. Gejala objektif hipertensi porta yang dapat ditemukan adalah ascites, hepatosplenomegali, varises esofagus, dan peritonitis bakteri spontan. Komplikasi lain akibat penurunan fungsi hati adalah gangguan fungsi pembekuan darah, osteoporosis, kelainan hematologi, seperti anemia, hemolisis, trombositopenia, dan neutropenia, encephalopathy hepaticum, sindrom hepatorenal, sindrom hepatopulmonal, serta kanker hepatoseluler. ${ }^{8}$

Dalam mendiagnosis sirosis, diperlukan anamnesis mengenai riwayat kesehatan pasien sebelumnya, riwayat penyakit keluarga, riwayat konsumsi alkohol dan obat-obatan. Gejala klinis, terutama di tahap awal, tidak bisa menjadi patokan untuk mendiagnosis sirosis. ${ }^{6}$ Pemeriksaan darah diperlukan untuk melihat gambaran dari fungsi hati. Pemeriksaan itu mencakup pemeriksaan antigen hepatitis virus B dan C, darah lengkap, kadar albumin, bilirubin serum, waktu perdarahan dan pembekuan darah, fungsi hati, serta fungsi ginjal. ${ }^{10}$ Pemeriksaan penunjang lain yang dapat dilakukan adalah ultrasonography (USG), computerized tomography (CT) scan, dan magnetic resonance imaging (MRI). Agar penyakit hati kronik dapat didiagnosis lebih dini, maka diperlukan pemeriksaan penunjang yang dapat menilai sirosis hati pada stadium awal. Saat ini, pemeriksaan baku emas yang digunakan adalah biopsi hati. Biopsi dilakukan dengan mengambil sebagian jaringan hati dengan menggunakan jarum halus dan dipandu dengan menggunakan USG atau CT Scan. Setelah dilakukan biopsi, pasien perlu dimonitor selama 2-4 jam sebelum diperbolehkan pulang. ${ }^{6}$ Pemeriksaan biopsi memiliki beberapa kekurangan, yakni prosedur yang invasif, memerlukan waktu lama, dan pengambilan sampel yang terbatas sehingga kurang representatif. Karena adanya kekurangan tersebut, mulai dikembangkan metode deteksi dini lainnya, yaitu elastografi. ${ }^{4}$

\section{Elastografi}

Terjadinya fibrosis pada parenkim hati, menyebabkan penurunan elastisitas dari jaringan hati. Keadaan inilah yang menjadi dasar dari penilaian pemeriksaan elastografi. Pada 


\section{Review Article}

awalnya, keadaan kekakuan dari jaringan hati dinilai menggunakan pemeriksaan fisik secara palpasi. Namun pemeriksaan secara palpasi memiliki banyak keterbatasan, yaitu penilaian yang terlalu subjektif dan sulit karena letak anatomi dari hati yang cukup dalam dari permukaan kulit. Karena keterbatasan tersebut, dikembangkan teknik pemeriksaan baru yakni elastografi. ${ }^{11}$

Elastografi adalah teknik pencitraan yang lebih menjanjikan dibandingkan teknik pengukuran kuantitatif lainnya, seperti CT-scan, MRI, dan USG konvensional. Hal ini didasari karena elastic modulus suatu jaringan yang diukur dengan teknik elastografi, akan mampu memberikan gambaran karakteristik yang paling luas. Urutan besarnya elastic modulus sekitar lima kali lipat lebih baik daripada modalitas pencitraan lainnya. Hal ini berarti bahwa penggunaan elastic modulus dapat memaksimalkan perbedaan antara jaringan yang berbeda, atau antara jaringan yang normal dan lesi. Elastic modulus diartikan sebagai kemiringan dari kurva tegangan-regangan selama deformasi yang elastis. Dengan demikian, objek yang keras akan memiliki elastic modulus yang paling tinggi. Dalam pendekatan terhadap pencitraan yang elastis, terdapat tiga langkah dasar, yakni aplikasi eksitasi, pengukuran respons dari jaringan, dan estimasi parameter secara mekanik. ${ }^{12}$

Elastografi terbagi atas dua jenis, yakni elastografi kualitatif dan elastografi kuantitatif. Elastografi kualitatif disebut juga dengan real-time elastography (RTE). RTE menilai fibrosis hati dengan menilai regangan yang terjadi pada jaringan ketika "shear wave" diberikan dengan penekanan menggunakan probe dari USG. Hasil dari pemeriksaan ini digambarkan berdasarkan perbedaan warna yang dihasilkan dari jaringan. Warna biru menunjukkan area jaringan hati dengan konsistensi yang keras, warna hijau menunjukkan konsistensi sedang dan warna merah menunjukkan konsistensi yang lunak. ${ }^{11,13}$

Elastografi kuantitatif disebut juga elastografi mekanik. Pemeriksaan ini membutuhkan alat yang lebih kompleks, yakni alat untuk memberikan "shear wave" pada jaringan hati dan alat radio imaging untuk melihat gambaran jaringan hati selama diberikan penekanan. Berdasarkan jenis "shear wave"-nya, elastografi kuantitatif dibagi atas dua jenis, yaitu elastografi kuantitatif dengan metode getaran mekanik dan elastografi kuantitatif dengan metode radiasi. Untuk jenis radioimaging, dapat digunakan USG dan MRI. ${ }^{11,14}$

Fibroscan, merupakan alat elastografi yang pertama dan banyak digunakan. Alat ini menggunakan metode "shear wave" berupa getaran mekanik, yang bekerja dengan cara memberikan stress getaran mekanik dengan frekuensi rendah, yaitu $50 \mathrm{~Hz}$, yang disebarkan pada jaringan hati. Selanjutnya, elastisitas hati dinilai menggunakan USG. Alat ini mampu memeriksa jaringan hati dengan luas permukaan seratus kali lebih luas dibandingkan ukuran 


\section{Review Article}

sampel yang diambil dari biopsi hati, sehingga hasil pemeriksaan lebih representatif dalam menggambarkan sirosis hati. ${ }^{11}$

Pasien diperiksa dalam keadaan terlentang dengan lengan kanan diangkat $180^{\circ}$, kemudian pemeriksa meletakkan probe di area sela iga yang menutupi hati. Hasil pemeriksaan yang diperoleh berupa nilai elastisitas jaringan hati terhadap stress yang diberikan dalam satuan kilopaskal $(\mathrm{kPa})$. Hasil pemeriksaan dinyatakan valid apabila memenuhi syarat sebagai berikut: dalam sepuluh kali pemeriksaan, rasio keberhasilan pemeriksaan $\geq 60 \%$ dan nilai variabilitas $<30 \%$. Nilai elastisitas normal adalah $<5.5 \mathrm{kPa}$. Nilai 5,5-7,0 kPa menyatakan fibrosis ringan, nilai 7,0 - 9,5 $\mathrm{kPa}$ menyatakan fibrosis sedang, nilai 9,5-12,5 $\mathrm{kPa}$ menyatakan fibrosis berat, sedangkan nilai > 12,5 $\mathrm{kPa}$ menyatakan sirosis hati. Kelemahan dari alat ini adalah ketidakmampuan dalam menilai fibrosis pada pasien dengan index massa tubuh (IMT) $>30$ $\mathrm{kg} / \mathrm{m}^{2}$ dan pasien dengan asites. ${ }^{11,16}$

Teknik elastografi lainnya adalah dengan metode "shear wave" berupa radiasi. Alat ini menyebarkan stress mekanik pada jaringan hati dengan menggunakan tenaga suara ultra terfokus, elastisitas dinilai dengan USG doppler. Keuntungan teknik ini adalah dapat digunakan pada pasien dengan asites. Nilai elastisitas jaringan hati menggunakan satuan dan rentang nilai yang sama seperti pada fibroscan. ${ }^{14}$

Berdasarkan meta-analisis yang dilakukan pada penderita hepatitis kronik, elastografi memiliki sensitivitas $78 \%$ dan spesifitas $80 \%$ dalam mendeteksi adanya fibrosis. Sedangkan pada penderita sirosis hati, elastografi memiliki sensivitas $83 \%$ dan spesifisitas $90 \%$. Elastografi merupakan alat screening yang baik, namun kurang akurat dalam menilai derajat fibrosis karena belum memiliki nilai cut off yang tervalidasi. Studi lain pada 246 pasien NAFLD menunjukkan bahwa elastografi dapat menilai derajat ringan, sedang, dan berat dari suatu fibrosis, namun kurang reliabel dalam menentukan derajat steatosis dan derajat inflamasi. ${ }^{14,17}$

\section{Aplikasi Elastografi ${ }^{12}$}

\section{Fibrosis hati}

Dalam penggunaan elastografi untuk menilai pengerasan hati, terdapat banyak studi klinis dalam mendiagnosis fibrosis hati yang menggunakan transient elastography. Suatu metaanalisis tentang pasien hepatitis $\mathrm{C}$ kronik, menyatakan bahwa nilai cut-off untuk fibrosis yang signifikan adalah $7,71 \mathrm{kPa}$ dengan sensitivitas $72 \%$ dan spesifisitas $82 \%$. Pada pasien dengan sirosis hati, hasil menunjukkan nilai cut-off 15,08 kPa dengan sensitivitas $84 \%$ dan spesifisitas 95\%. Meta-analisis lain dari 40 studi yang memenuhi syarat, memberikan hasil kesimpulan berupa nilai sensitivitas $78 \%$ dan spesifisitas $80 \%$ untuk fibrosis yang signifikan, serta $83 \%$ dan 


\section{Review Article}

90\% untuk sirosis. Sebagai tambahan, meta-analisis ini juga menyarankan penggunaan transient elastography sebagai alat pemeriksaan screening yang baik untuk sirosis, tetapi bukan sebagai alat diagnostik yang akurat untuk penentuan staging dari fibrosis hati. Hal ini disebabkan karena belum ada cut-off optimal yang tervalidasi terhadap staging dari fibrosis hati.

Rasio elastisitas adalah rasio nilai pada pembuluh darah vena kecil dibanding nilai pada parenkim. Rasio ini pada real-time elastography akan dihitung guna menentukan pengerasan hati. Performa diagnostik teknik ini lebih baik daripada penanda biokimia tidak invasif lainnya, seperti aspartate aminotransferase to the platelet ratio index (APRI) dan indeks Forns.

Dibandingkan dengan pasien dengan hepatitis virus $\mathrm{C}$, nilai cut off untuk sirosis pada pasien dengan hepatitis virus B cenderung lebih rendah. Hal ini disebabkan karena area fibrosis hati pada sirosis makronodular relatif lebih kecil. Walaupun demikian, peningkatan pengerasan hati seharusnya diperhatikan pada pasien dengan hepatitis virus B kronik eksaserbasi akut.

\section{Non-alcoholic Fatty Liver Disease}

Spektrum NAFLD sangat luas, bervariasi dari perlemakan hati yang sederhana hingga NASH. Fibrosis hati dapat berkembang dan berlanjut menjadi sirosis hati. Meskipun transient elastography sulit untuk dilakukan pada pasien dengan obesitas karena jaringan lemak subkutan akan memperlemah pushing pulse, namun kini telah dikembangkan teknik baru berupa alat vibration-controlled transient elastography. Alat ini mampu menghitung controlled attenuation parameter (CAP) yang baru. CAP bermanfaat untuk memperkirakan steatosis hati secara akurat dan tidak invasif.

Transient elastography dapat bermanfaat untuk mengklasifikasikan pasien dengan risiko yang tidak jelas. Jika pengerasan hati kurang dari 7,9 $\mathrm{kPa}$, maka fibrosis advanced dapat dieksklusi dengan negative predictive value (NPV) 97\%. Sebaliknya, jika nilai pengerasan hati lebih dari 9,6 kPa, maka diagnosis fibrosis advanced dapat dibuat dengan positive predictive value (PPV) 72\%. Dengan demikian, hanya pasien dengan nilai 7,9-9,6 kPa yang membutuhkan biopsi hati untuk penegakan diagnosis. Hal ini akan menurunkan angka indikasi biopsi hati pada pasien NAFLD serta menurunkan insidens komplikasi akibat biopsi.

\section{Simpulan}

Alat pemeriksaan penunjang untuk mendeteksi dini jaringan fibrosis pada pasien dengan penyakit hati yang kronik sangat diperlukan. Saat ini, telah dikembangkan berbagai macam jenis elastografi, sebagai alternatif untuk menggantikan biopsi. Teknik elastografi 


\section{Review Article}

dengan metode "shear wave" berupa radiasi menjadi pilihan yang lebih baik karena mampu mendeteksi jaringan fibrosis pada pasien dengan asites.

\section{Daftar Pustaka}

1. Blachier M, Leleu H, Radosavljevic MP, Valla DC, Thoraval FR. The burden of liver disease in europe. EASL. 2013;1-47.

2. $\quad$ Starr SP, Raines D. Cirrhosis: diagnosis, management, and prevention. AFP. 2011; 84(12): 1352-8.

3. World Health Organization [database on the Internet], Liver Disease - [cited 2016 Jun 13]. Available from http://worldlifeexpectancy.com/country-health-profile/indonesia.

4. Fung JY, Lai CL, Yuen MF. Clinical application of transient elastography (fibroscan) in liver diseases. The Hong Kong Med Diary. 2009;14(11):22-4.

5. Tsao GG, Lim J. Management and treatment of patients with cirrhosis and portal hypertension. Am J Gastroenterol. 2009;104:1802-29.

6. $\quad$ Runyon BA, Gores G, Talwakar JA. Cirrhosis. NIH. 2014;14:1-14.

7. Xu Ruonan, Zhang Z, Wang FS. Liver fibrosis: mechanism of immune-mediated injury. Cell Mol Immunol. 2012;9:296-301.

8. Bacon BR. Cirrhosis and its complications, In: Fauci AS, Braunwald E, Kasper DL, Hauser SL, Longo DL, Jameson JL, et al, editors. Harrison's principles of internal medicine. $17^{\text {th }}$ Edition. New York: The McGrawHill; 2008. p. 1971-80.

9. Fleming CM. The epidemiology of cirrhosis and abnormal liver function in the general population of the UK. The University of Nottingham. 2010;46-8.

10. Castillo AL, Pineda FP, Cardenas EO, Avila FS, Vorackova FV. AST to platelet ratio index (APRI) for the non-invasive evaluation of liver fibrosis. Annal of Hepatology. 2008;7(4):350-7.

11. Laurent S, Jennifer O, Cecile B, Celine F, Veronique M, Sebastian M. Non-invasive assessment of liver fibrosis by vibration-controlled transient elastography. INTECH. 2011;19:293-309.

12. Jeong WK, Lim HK, Lee HK, Jo JM, Kim Y. Principles and clinical application of ultrasound elastography for diffuse liver disease. Ultrasonography. 2014;33:149-160.

13. Paparo F, Corradi F, Cevasco L, Revelli M, Marziano A, Molini L, et al. Real-time elastography in the assesment of liver fibrosis: a review of qualitative and semi-quantitative methods for elastogram analysis. Ultrasound in Med \& Biol. 2014;40(9):1923-33.

14. Ferraioli G, Parekh P, Levitov AB, Filice C. Shear wave elastography for evaluation of liver fibrosis. J Ultrasound Med. 2014;33:197-203.

15. Kemp W, Robert S. FibroScan and transient elastography. Aust Fam Physician. 2013;42(6):468-70.

16. Sporea I, Sirli R. What to expect from fibroscan (transient elastography) for the evaluation of chronic hepatopathies?. Medical Ultrasonography. 2008;10(1):7-11.

17. Sumantri S. Penggunaan transient elastography untuk staging dan grading pada pasien NAFLD. Evidence Based Clinical Review. 2010;1-14. 